\title{
Dinoflagellate cyst distributions and the Albian-Cenomanian boundary (mid-Cretaceous) at Cordebugle, NW France and Lewes, southern England
}

\author{
BRUCE A. TOCHER' \& IAN JARVIS ${ }^{2}$ \\ 'Palynological Research Centre, Institute of Earth Studies, University of Wales, Aberystwyth, Dyfed SY23 3DB, UK. \\ ${ }^{2}$ School of Geological Sciences, Kingston University, Penrhyn Road, Kingston upon Thames, Surrey KT1 2 EE, UK.
}

\begin{abstract}
The Albian-Cenomanian boundary successions at Livet Quarry, Cordebugle and Rodmell Cement Works, Lewes are described. Moderately abundant and diverse dinoflagellate cyst assemblages comprising 89 taxa are recorded and related to ammonite, foraminiferal and other faunal data from the two sites. The genus Ovoidinium forms a major component of cyst assemblages from the boundary intervals at both localities. Ovoidinium scabrosum (Cookson \& Hughes) Davey is replaced by abundant Ovoidinium verrucosum verrucosum (Cookson \& Hughes) Davey close to, and possibly at, the stage boundary, offering a potential dinoflagellate cyst marker for the base of the Cenomanian Stage. The published ranges of a number of species are extended. Six taxa are recorded for the first time from NW Europe: Apteodinium reticulatum Singh, Disphaeria macropyla Cookson \& Eisenack, Nematosphaeropsis densiradiata (Cookson \& Eisenack) Stover \& Evitt and Pervosphaeridium cenomaniense (Norvick) Below occur in the high Upper Albian; Ovoidinium verrucosum (Cookson \& Hughes) ostium (Davey) Lentin \& Williams and Tanyosphaeridium salpinx Norvick are recorded from the lowest Lower Cenomanian. Increased cyst abundance and diversity at Lewes when compared with Cordebugle is related to the more basinal setting of the former locality. $J$. Micropalaeontol. 15(1): 55-67. April 1996.
\end{abstract}

\section{INTRODUCTION}

The Cenomanian Stage, at the base of the Upper Cretaceous Series, is marked throughout most of NW Europe by the appearance of pelagic carbonates (chalks and marls), replacing dominantly siliciclastic sediments (sandstones and mudstones) of the Lower Cretaceous. This major lithological change was a consequence of the continuing rise in eustatic sea-level, that began in the earliest Cretaceous and which, by the Early Cenomanian, had drowned most available siliciclastic source areas, to form a broad shallow epicontinental sea (Hancock \& Kauffmann, 1979; Juignet, 1980; Hancock, 1990, 1992). The sharp lithological change which occurs regionally at the bottom of the Cenomanian has recently been confirmed as a major sequence boundary, and is generally associated with a small hiatus (Amédro, 1992; Hart et al., 1992; Juignet \& Breton, 1992; Robaszynski et al., 1992). This was probably caused by a minor regressive event (Cooper, 1977; Haq et al., 1987; Simmons et al., 1991; Amédro, 1992) or period of still-stand (Hancock, 1989), superimposed on the main mid-Cretaceous sea-level rise.

In this paper, we describe the dinoflagellate cyst distributions of samples taken across two AlbianCenomanian boundary intervals, one from NW France and the other from southern England. Samples of $10 \mathrm{~g}$ were processed using standard palynological acid digestion techniques, and the strew mounts examined under a light microscope. Slides and residues are stored in the reference collection of the Palynological Research Centre, Institute of Earth Studies, University of Wales, Aberystwyth, UK. In all cases, samples were precisely located within existing detailed litho- and biostratigraphic frameworks, enabling new observations to be made on the ranges and assemblages of dinoflagellate cysts during the Early-Late Cretaceous transition.

\section{CORDEBUGLE}

Cordebugle, $10 \mathrm{kr}$ SE of Lisieux, département of Calvados, NW France, is situated close to the western limit of the 'Normandy Basin' (Juignet, 1980; Juignet \& Breton, 1992), a structurally and sedimentologically distinct area located on the western margin of the Cretaceous Anglo-Paris Basin (Fig. 1). The region lies less than $100 \mathrm{~km} \mathrm{NE}$ of the Armorican Massif, a significant local source of sediment through most of the Cenomanian which resulted in the accumulation of thick siliciclastic packages on the adjacent 'Maine Platform'. However, further to the northeast, coeval Normandy deposits are dominantly pelagic, if somewhat marginal in nature. Thick glauconitic sands (the Gaize and Glauconie de base) of Albian age are here overlain by cherty, locally sandy, glauconitic Cenomanian chalks with prominent hardgrounds at several levels.

Livet Quarry, situated to the west of Cordebugle village (Fig. 1), is a large working sand pit which exposes more than $30 \mathrm{~m}$ of mid-Cretaceous (Aptian-Cenomanian) sediments resting unconformably on Upper Jurassic (Oxfordian) sands and clays. The quarry (Coordonées Lambert of the Institut géographique National de France: $\mathrm{x}=455,40 ; \mathrm{y}=157,80$ ) has been described previously by Juignet (1974). Thirteen samples (Crd. 1-13) were collected across the AlbianCenomanian boundary (Figs 2, 3). All of the residues contained palynomorphs, and a total of 66 species and subspecies of dinoflagellate cysts have been recorded (representative specimens are illustrated in Plates 1, 2; 


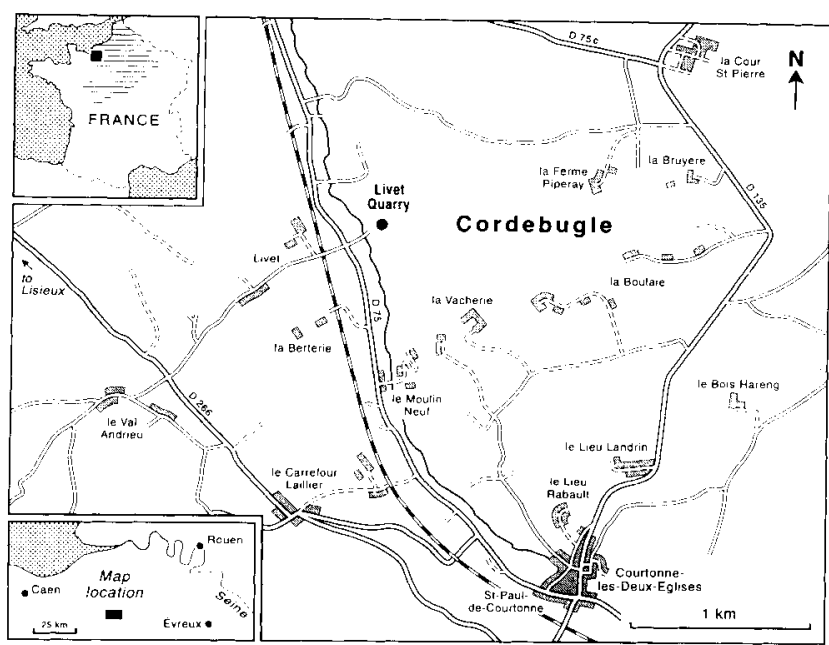

Fig. 1. Location maps for Livet Quarry, Cordebugle. The regional map (upper left) shows the position of the study area in relation to the Cretaceous Anglo-Paris Basin (horizontal ornament).

\section{Lithological key:}

\begin{tabular}{|c|c|c|c|}
\hline$-\infty$ & nodular chert & 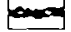 & semi-tabular chert \\
\hline & white chalk & $5^{5} 3^{5}$ & sponge debris \\
\hline$=\div$ & marly chalk & $\therefore \therefore$ & shelf debris \\
\hline$=2$ & marl & $\infty$ & calcareous nodules \\
\hline 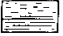 & silty clay & $\because \cdots$ & phosphatic nodules \\
\hline & glauconite sand & wwn & omission surface \\
\hline$\because \because \therefore]$ & quartz gravel & 8.0 .0 & crustacean burron \\
\hline
\end{tabular}

Fig. 2. Key to main lithologies occurring in the Cordebugle and Lewes sections (Figs 3, 5).

Appendix 1). Since many samples yielded $<200$ individuals, cyst abundances are reported as absolute numbers (Fig. 3).

\section{Lithostratigraphy}

Approximately $19 \mathrm{~m}$ of Aptian shallow-marine sands and gravels (Sables ferrugineux Formation) overlie the Cretaceous unconformity at Cordebugle. Above this, more than $15 \mathrm{~m}$ of glauconitic Albian-Cenomanian sediments, the Glauconie de base and Craie glauconieuse Formations, are exposed.

Glauconie de base The Glauconie de base rests with a sharp contact on a thin $(10 \mathrm{~cm})$ iron-cemented pebbly sandstone at the top of the Sables ferrugineux. Our first sample (Crd. 1) was taken $30 \mathrm{~cm}$ above this contact. The Glauconie de base (Figs 2,3) comprise $7.3 \mathrm{~m}$ of extremely glauconitic sands, with coarse-grained lenses, interbedded with more argillaceous horizons. The sediments are heavily bioturbated at several levels, and yield macrofossils from the upper beds. A distinctive omission surface overlain by glauconitic sands and gravels (Crd. 2) containing small black phosphatic nodules occurs $1.8 \mathrm{~m}$ above the base. Abundant fauna, dominantly bivalves and brachiopods, occur at two levels: the lower (Crd. 5) is a $1.0 \mathrm{~m}$ thick bed containing calcareous nodules with sponges; the upper (Crd. 7) occurs at the summit (top 0.9 $m$ ) of the formation. A thick coarse-grained dark green glauconitic sand (Crd. 6) containing abundant crustacean burrows, Spongeliomorpha annulatum Kennedy, occurs between these two beds.

Craie glauconieuse de St Jouin The base of the Craic glauconieuse de St Jouin is marked by a prominent omission surface (Juignet \& Breton, 1992; Fig. 3) overlain by green to dark brown bioturbated glauconitic sands (Crd. 8) containing S. annulatum and fragments of bivalve shells. The St Jouin Formation is accessible for approximately $6 \mathrm{~m}$ and comprises green and dark brown glauconitic sediments at the base, passing up into paler-coloured marly sediments above. Scattered, partly silicified, carbonate nodules are common in the middle of the sequence, below and immediately above a well-developed omission surface termed the 'Livet' surface by Juignet (1974). Above this, there is a dramatic change in lithology with glauconitic marls at the very base (Crd. 12) overlain (Fig. 3 ) by creamy-brown marly chalks containing numerous closely spaced tabular and semi-tabular bands of large, irregular, cavernous grey cherts.

\section{Biostratigraphy}

Macrofossils records, particularly ammonites, provide the initial means of constraining the age of the succession at Cordebugle, but further biostratigraphic refinement has been possible by incorporating our new palynological data.

Glauconie de base The lowest macrofaunal records from the Glauconie de base are from $3.5 \mathrm{~m}$ above the bottom of the formation, where the ammonite Sharpeiceras laticlavium (Sharpe) has been recorded (Juignet, 1974) in association with abundant bivalves, Lima sp., Chlamy sp., and brachiopods, Cyclothyris difformis (Valenciennes in Lamarck) and terebratulids. The occurrence of Sharpeiceras clearly demonstrates that this bed is Lower Cenomanian (Wright \& Kennedy, 1984, 1987a). Additional ammonite records from the overlying Craie glauconieuse (see below), indicate that this level must lie within the lowest Lower Cenomanian Neostlingoceras carcitanense Subzone of the Mantelliceras mantelli Zone. However, in the absence of definitive Albian taxa, macrofaunal records do not allow the Albian-Cenomanian boundary to be placed in the succession with any confidence. The top of the Glauconie de base contains large sponges, bivalves Spondylus striatus (J. Sowerby), Gryphaeostrea canaliculata (J. Sowerby), Inoceramus sp., Chlamys sp., Lima sp. and brachiopods, principally Cyclothyris difformis and terebratulids.

Seven samples (Crd. 1-7) were collected from the Glauconie de base for palynological analysis. Samples Crd. 2-4 displayed the incoming of a number of stratigraphically significant taxa, including Endoceratium dettmanniae (Cookson \& Hughes) Stover \& Evitt; emend. Harding \& Hughes, Florentinia deanei (Davey \& Williams) Davey \& Verdier, Ovoidinium verrucosum verrucosum (Cookson \& Hughes) Davey, Exochosphaeridium bifidum (Clarke \& 


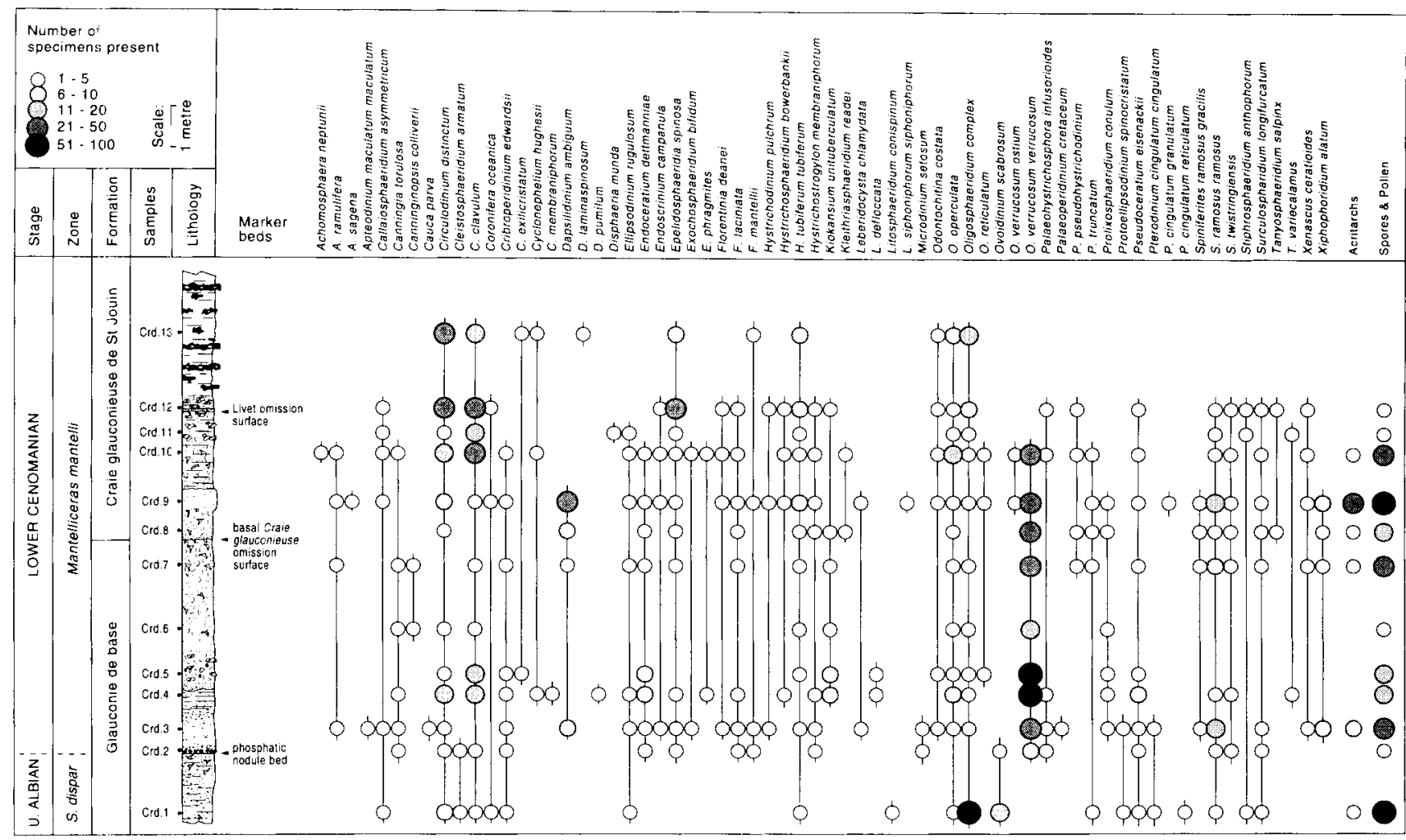

Fig. 3. Stratigraphy and palynomorph distribution across the Albian-Cenomanian boundary at Livet Quarry, Cordebugle. Cyst abundances plotted as absolute numbers recovered. See Fig. 2 for lithological key.

Verdier) Clarke et al., Hystrichosphaeridium bowerbankii Davey \& Williams, Prolixosphaeridium conulum Davey, Cyclonephelium hughesii Clarke \& Verdier and Leberidocysta defloccata (Davey \& Verdier) Stover \& Evitt, whose first appearances elsewhere are taken to indicate strata of latest Albian ( $S$. dispar ammonite Zone) age (Davey \& Verdier, 1973; Fauconnier, 1979; Foucher, 1981; Costa \& Davey, 1992).

The last appearances of Litosphaeridium conispinum Davey \& Verdier; emend. Lucas-Clark and Protoellipsodinium spinocristatum Davey \& Verdier (Pl. 2, fig. 11) occur in our lowest samples from the Glauconie de base (Crd, 1 and 3 respectively). These species have not been recorded previously from sediments above the Upper Albian Mortoniceras (Mortoniceras) inflatum ammonite Zone (Davey \& Verdier, 1973; Foucher, 1981; Costa \& Davey, 1992). Certainly, our lowest sample at Cordebugle (Crd. 1) contains a very different dinoflagellate cyst assemblage [dominated by Oligosphaeridium complex (White) Davey \& Williams with subordinate Ovoidinium scabrosum (Cookson \& Hughes) Davey; Pl. 2, fig. 3] compared to the immediately overlying beds containing typical $S$. dispar Zone forms. No macrofauna have been recovered from this part of the sequence, so it is possible that the lowest beds of the Glauconie de base (i.e. below the phosphatic nodule bed) are $M$. (Mortoniceras) inflatum Zone. However, P. spinocristatum (Crd. 3; Pl. 2, fig. 11) is also recorded higher in the succession at Cordebugle and at Lewes (see below) together with assemblages of typical $S$. dispar Zone dinofiagellate cysts, indicating that the species must extend further up in the Upper Albian than recognized previously. Similarly, although $L$. conispinum is recorded only from our basal sample at Cordebugle, it was also recovered from the $S$. dispar Zone at Lewes. The age of the oldest beds of the Glauconie de base, therefore, remains uncertain, but on balance, is most probably $S$. dispar Zone.

Craie glauconieuse de St Jouin Phosphatized fragmented internal moulds of ammonites [Schloenbachia varians (J. Sowerby) subplana, S. varians subtuberculata, S. varians subvarians], along with sponges, Inoceramus sp. and bryozoans, occur approximately $2 \mathrm{~m}$ above the base of the St Jouin Formation. The ammonite assemblage confirms the Cenomanian age of this bed (Wright \& Kennedy, 1987b), a dominance of Schloenbachia spp. being common in the lowest Lower Cenomanian $N$. carcitanense Subzone (Hancock, 1991).

A more diverse phosphatised ammonite fauna has been recorded (Juignet, 1974) from immediately above the Livet Omission Surface, including abundant Neostlingoceras carcitanense (Matheron), together with Anisoceras jacobi (Breistroffer), Hyphoplites falcatus falcatus (Mantell), $H$. curvatus arausionensis (Hébert \& Munier-Chalmas), $H$. curvatus curvatus (Mantell), S. varians subplana and Forbesiceras largilliertianum (d'Orbigny). This assemblage is 

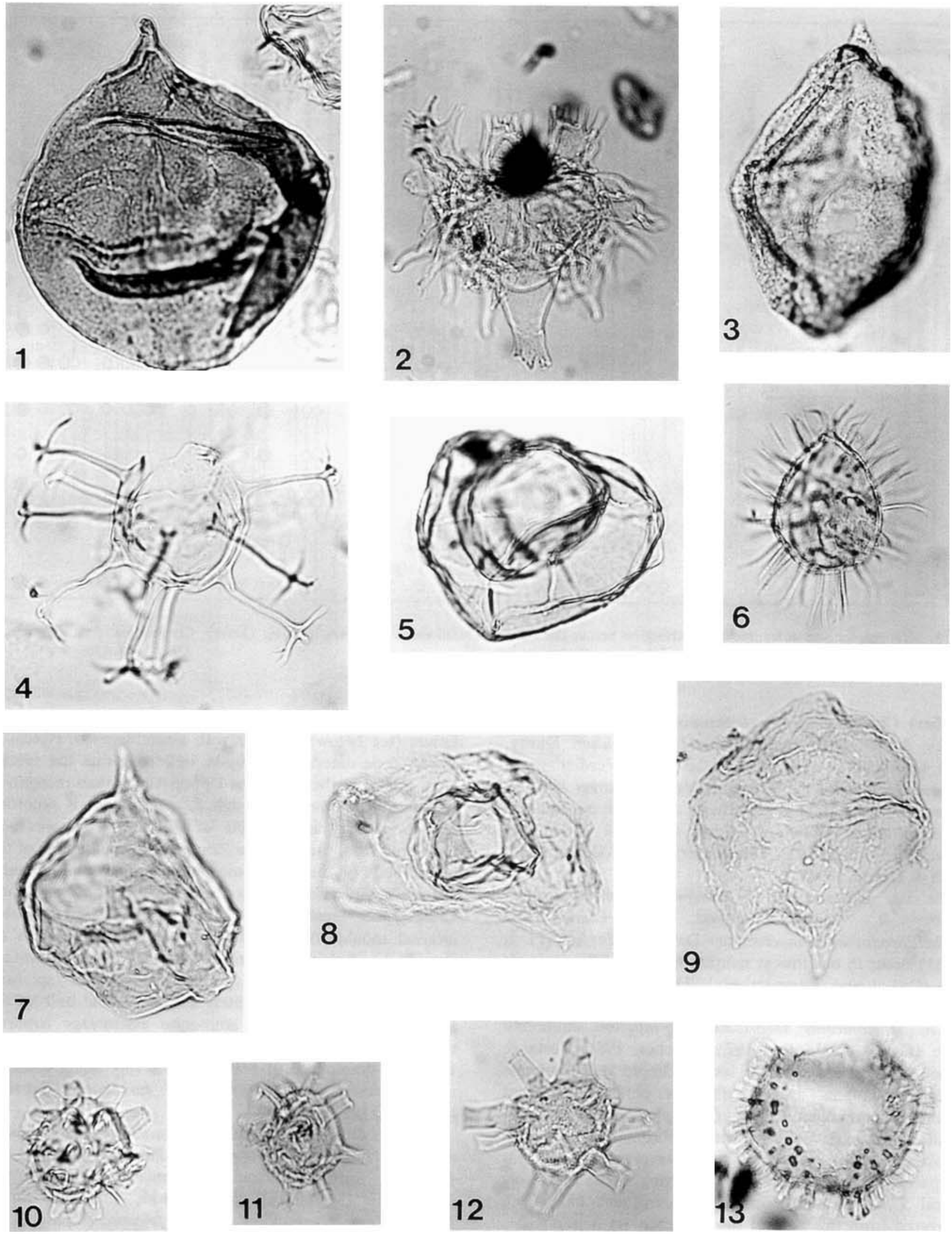

Plate 1 
typical of the N. carcitanense Subzone. Mantelliceras cantianum Spath provides the only biostratigraphically useful macrofossil recovered from the cherty upper beds of the Craie glauconieuse, although ammonite records from elsewhere in the region (Juignet, 1974) suggest that the base of the overlying mid-Lower Cenomanian $M$. saxbii Subzone lies above the exposed section at Cordebugle.

Several stratigraphically significant dinoflagellate cysts have been recorded from the Craie glauconieuse. Most importantly, the last appearances of Canningia torulosa Davey \& Verdier and $O$. verrucosum verrucosum (Cookson \& Hughes) Davey occur within the lower beds (Crd. 10) of the Craie glauconieuse, indicating that this part of the succession is basal Lower Cenomanian (Foucher, 1981; Costa \& Davey, 1992). This conclusion is confirmed by the presence of a Schloenbachia-dominated ammonite assemblage (see above) at this level.

Two dinoflagellate cysts species are recorded for the first time from the Anglo-Paris Basin. Ovoidinium verrucosum (Cookson \& Hughes) ostium (Davey) Lentin \& Williams (Crd. 9, 10) has previously been described from Albian-Lower Cenomanian strata in Saskatchewan (Davey, 1970), and Tanyosphaeridium salpinx Norvick which occurs in the Lower Cenomanian at Cordebugle (Crd. 8, 12), but has only been recorded before firom Aptian-Albian strata in Australia (Norvick, 1976; Morgan, 1980).

\section{LEWES}

Lewes lies $9 \mathrm{~km}$ north of the East Sussex coast of southern England. The Upper Cretaceous of this region is characterized by thick successions of basinal chalks (Rawson et al., 1978; Mortimore \& Pomerol, 1987), typical of the central Anglo-Paris Basin. The supply of coarse detritus was cut-off to the area in the latest Aptian, the Albian being represented by a thick succession of silts and clays (Lake et al., 1987) passing up, via a thin development of glauconitic marls, into a pelagic carbonate sequence of rhythmically bedded marls and limestones in the Cenomanian. No Upper Albian sands (Upper Greensand Formation) occur around Lewes, although this facies is well developed in coastal exposures at Eastbourne, $23 \mathrm{~km}$ to the southeast.

Rodmell Cement Works, $4 \mathrm{~km}$ SE of Lewes, once a complex of three pits (Fig. 4), now almost entirely infilled, prior to 1991-2 exposed strata ranging from Upper Albian to Lower Turonian. The locality (also referred to in the literature as Beddingham Limeworks) was described previously by Gaster (1929), Kennedy (1969), Carter \& Hart (1977), Wright \& Kennedy (1984) and Lake et al. (1987). Borehole data from the quarry were presented by Price (1977) and Lake et al. (1987). The Albian-Cenomanian boundary was exposed on the edge of a large flooded clay pit (Fig. 4, Pit 1; UK National Grid Reference: TQ 441 071). The Lower-Middle Cenomanian was best seen in an adjacent pit (Pit 2, TQ 438 067), $500 \mathrm{~m}$ to the south.

Five samples (Rod. 1-5) were collected across the Albian-Cenomanian boundary for palynological analysis; one additional sample (Rod. 6) was obtained from the Middle Cenomanian. Each preparation contained a diverse assemblage of dinoflagellate cysts, a total of 85 cyst taxa being recorded (Fig. 5; Plates 1, 2; Appendix 1). Since all samples yielded several hundred individuals, cyst occurrences are reported as percentage abundances (Fig 5), based on counts of 200 individuals per slide.

\section{Lithostratigraphy}

More than $25 \mathrm{~m}$ of section, including the uppermost beds of the Upper Gault Clay Formation (Upper Albian) and the lower beds of the Lower Chalk Group, Glauconitic Marl and overlying Chalk Marl Formations (Lower-Middle Cenomanian), were intermittently exposed in Rodmell Pits 1 and 2.

Upper Gault Clay The summit of the Upper Gault Clay was exposed at Rodmell Pit 1 (Fig. 4), where it consisted of approximately $1 \mathrm{~m}$ of blue-grey bioturbated silty clay, passing up into $3 \mathrm{~m}$ of light brown silty calcareous and micaceous bioturbated clay. The silt content increased towards the top of the succession and occasional thin diagenetically laminated units were present. The top of the Upper Gault was marked by a sharply defined omission surface which was penetrated by numerous glauconitic sand-filled Thalassinoides burrows (Fig. 5). The sediment within these burrows was identical to that which immediately overlay the omission surface, forming the basal facies of the Lower Chalk, Glauconitic Marl. The facies consisted of intensely bioturbated, light brown and green, friable, glauconitic marly sands. An unconformity of up to $15^{\circ}$ has been observed by other workers (Wright

\section{Explanation of Plate 1}

Representative Upper Albian-Lower Cenomanian dinoflagellate cysts from Cordebugle and Lewes. Figure captions include species name, author(s), sample number, preparation number, and England Finder co-ordinates. Samples are deposited in the reference collection of the Palynological Research Centre, Institute of Earth Studies, Aberystwyth. All specimens were photographed at $\times 500$. Fig. 1. Apteodinium maculatum (Eisenack \& Cookson, 1960) grande (Cookson \& Hughes, 1964) Below, 1981, Rod. 1, MCP/1293, H24/2. Fig. 2. Florentinia laciniata Davey \& Verdier, 1973; Crd. 4, MCP/3157, R27/2. Fig. 3. Apteodinium reticulatum Singh, 1971, Rod. 3, MCP/1291, R24/4. Fig. 4. Oligosphaeridium complex (White, 1842) Davey \& Williams, 1966, Rod. 1, MCP/1293, J49/4. Fig. 5. Stephodinium coronatum Deflandre, 1936, Rod. 1, MCP/1293, O31. Fig. 6. Coronifera oceanica Cookson \& Eisenack, 1958; emend. May, 1980, Crd. 1, MCP/3154, H27. Fig. 7. Apteodinium maculatum maculatum Eisenack \& Cookson, 1960, Rod. 3, MCP/1291, G18/2. Fig. 8. Disphaeria macropyla Cookson \& Eisenack, 1960; emend. Norvick in Norvick \& Burger, 1976, Rod. 3, MCP/1291, R46/2. Fig. 9. Palaeoperidinium cretaceum Pocock, 1962; emend. Davey, 1970; emend. Harding, 1990, Rod. 1, MCP/1293, D33 Fig. 10. Litosphaeridium conispinum Davey \& Verdier, 1973; emend. Lucas-Clark, 1984, Rod. 3, MCP/1291, T25. Fig. 11. Litosphaeridium arundum (Eisenack \& Cookson, 1960) Davey, 1979; emend. Lucas-Clark, 1984, Rod. 3, MCP/1291, K31/3. Fig. 12. Litosphaeridium siphoniphorum siphoniphorum (Cookson \& Eisenack, 1958) Davey \& Williams, 1966; emend. Lucas-Clark, 1984, Rod. 2, MCP/1292, L54/3. Fig. 13. Circulodinium distinctum (Deflandre \& Cookson, 1955) Jansonius, 1986, Crd. 1, MCP/3154, Q43/4. 

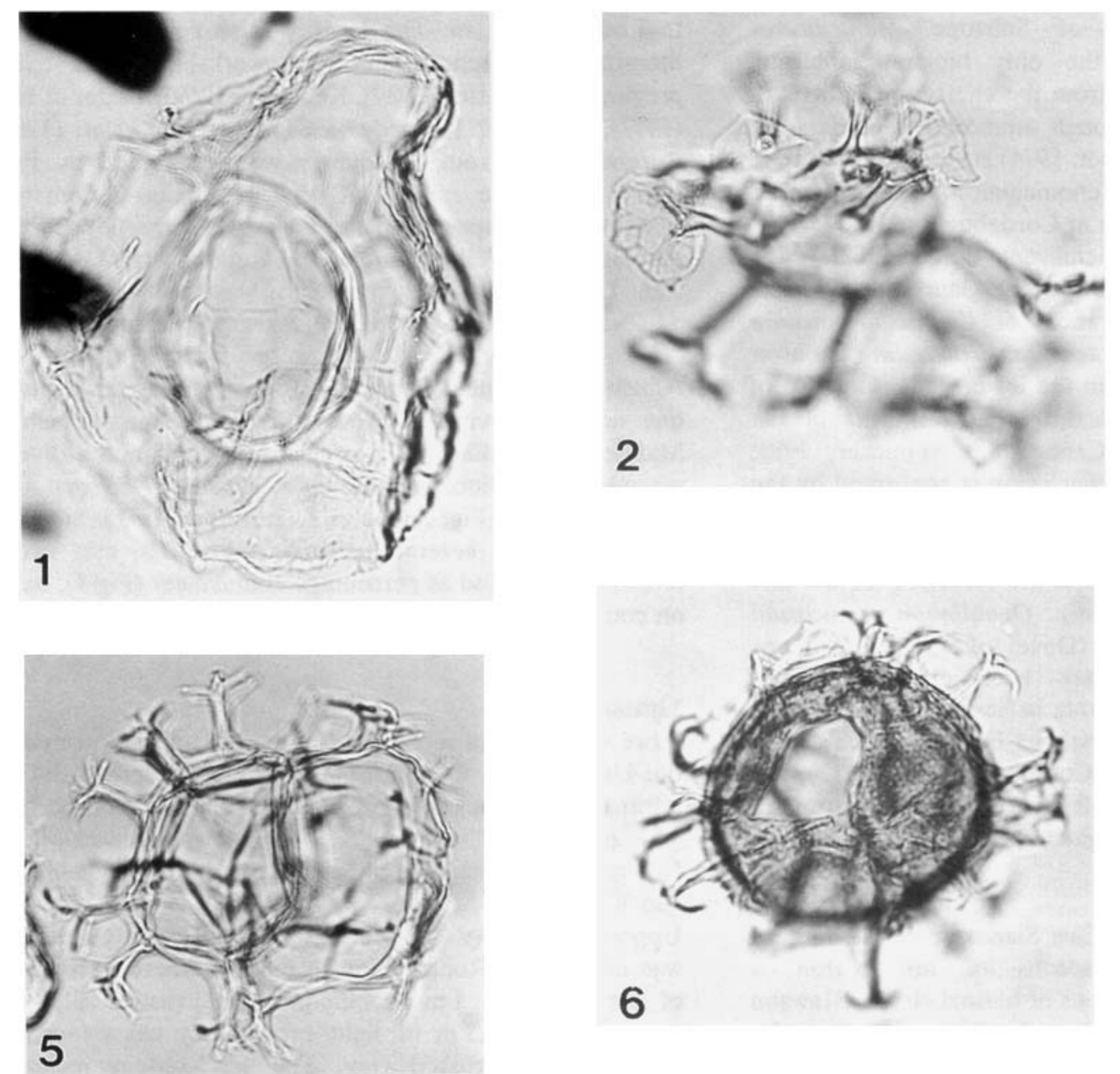
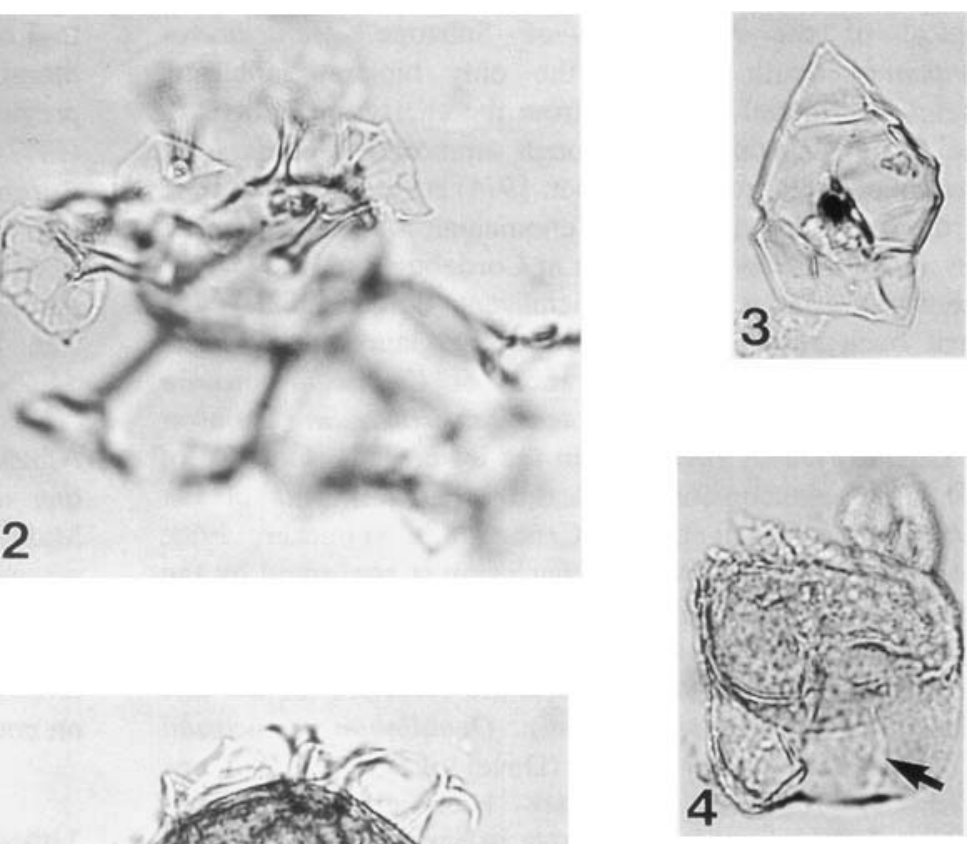

6
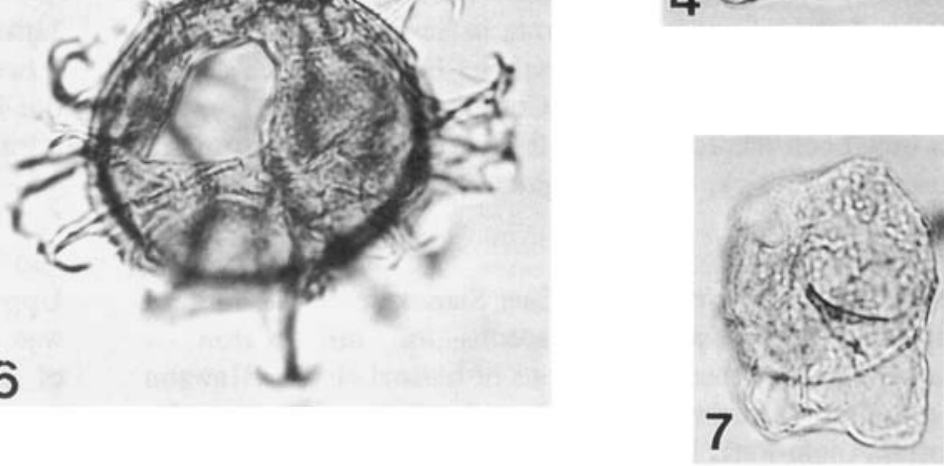

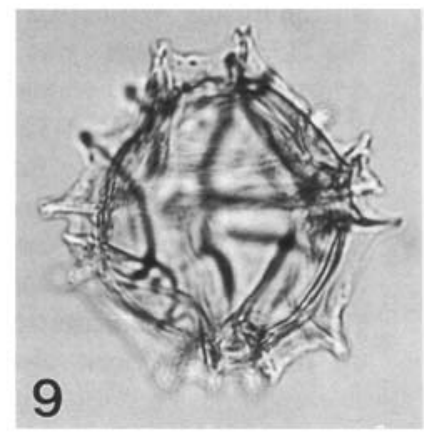

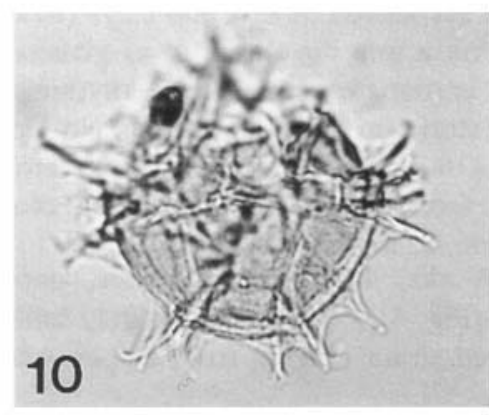

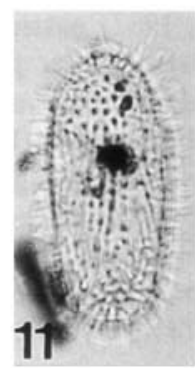

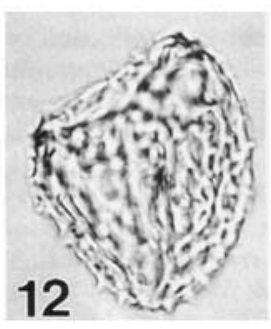
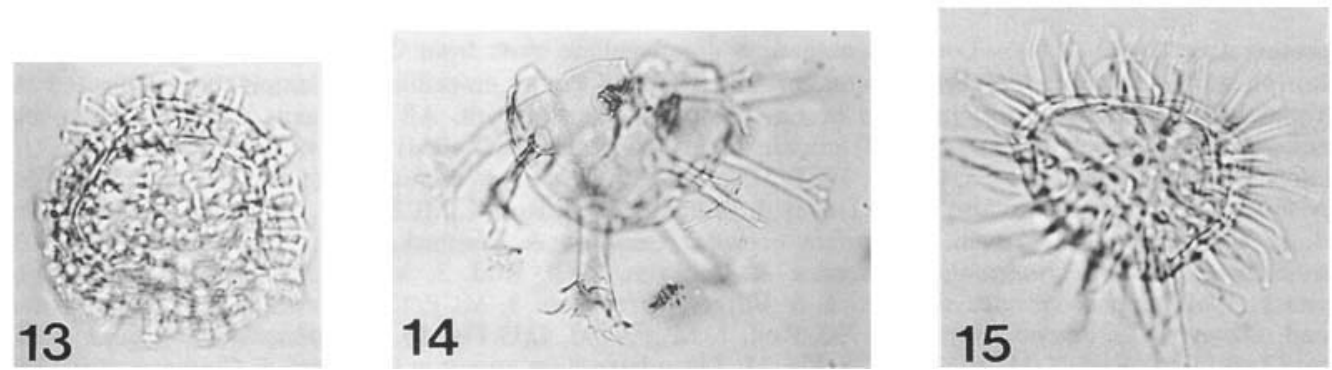

Plate 2 


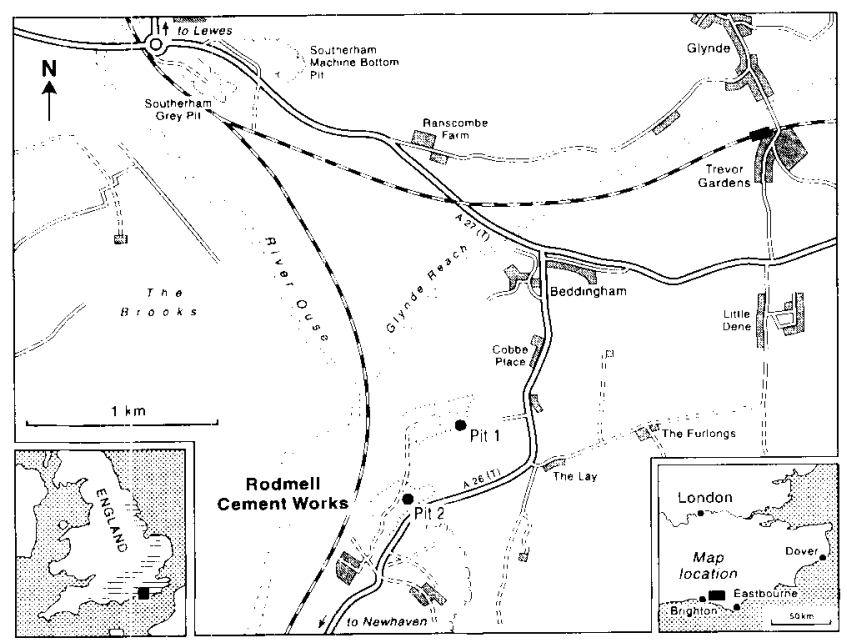

Fig. 4. Location maps for Rodmell Cement Works, Lewes. The regional map (bottom left) shows the distribution of major Cretaceous outcrops in the UK (horizontal ornament). The pits have now been largely filled and the site is being reclaimed for agricultural use.

\& Kennedy, 1984) between the Upper Gault and Glauconitic Marl.

Glauconitic Marl Abundant, small (1-3 cm), black phosphatic clasts and common bivalve shell fragments, including small Aucellina, occurred up to $15 \mathrm{~cm}$ above the base of the Glauconitic Marl. The glauconite content decreased rapidly upwards and virtually disappeared in a more indurated limestone which occurred at the top of the unit (Kennedy, 1969), and marked the boundary with the overlying Chalk Marl. Macrofossils were poorly preserved in the basal Glauconitic Marl, but prominent Thalassirioides and other burrows occurred throughout. Sparse ammonites and common Inoceramus crippsi Mantell have been recorded at the summit of the formation (Kennedy, 1969), which is approximately $1.5 \mathrm{~m}$ thick. Palynological samples (Fig. 5, Rod. 1-5) were taken across the Upper Gault/Glauconitic Marl boundary from $4 \mathrm{~m}$ below to $0.7 \mathrm{~m}$ above the contact.

Chalk Marl Nearby, in Rodmell Pit 2, intermittent exposures of Chalk Marl occurred within a $20 \mathrm{~m}$ thick succession of interbedded greyish white limestones and medium to pale grey marls. One small exposure near the summit of the succession contained abundant Orbirhynchia mantelliana (J. de C. Sowerby) brachiopods and Sciponoceras heteromorph ammonites, with common $I$. crippsi and echinoid fragments These beds have been termed the upper O. mantelliana band (Lake et al., 1987; $=O$. mantelliana band of Kennedy, 1969), and occur only a few metres below the boundary between the Chalk Marl and the overlying Grey Chalk Formation. A single sample was taken from this interval (Fig. 5, Rod. 6) for palynological analysis.

\section{Biostratigraphy}

Published macro- and microfossil records, principally ammonites and foraminifera, provide a means of determining the age of the succession at Rodmell. When combined with our new dinoflagellate cyst data, they enable a highly refined biostratigraphy to be developed.

Upper Gault Clay No stratigraphically significant macrofossils have been recorded from the summit of the Upper Gault at Rodmell. However, the foraminiferal assemblage in these beds (Carter \& Hart, 1977) includes large numbers of planktonic Globigerinelloides bentonensis (Morrow), indicative of the Upper Albian $G$. bentonensis Zone. Evidence of a stratigraphic gap at the Upper Gault/Glauconitic Marl contact is provided by the benthonic foraminiferal biostratigraphy (Carter \& Hart, 1977; Lake et al., 1987) which demonstrates that the uppermost Upper Albian (Zone 6a of Carter \& Hart, 1977; Zone 9 of Price, 1977) is absent. This suggests that the $S$. dispar ammonite Zone is incomplete, the top of the Gault at Rodmell probably falling within the lower part of the Mortoniceras (Durnovarites) perinflatum Subzone (Price, 1977; Lake et al., 1987).

Samples from the Upper Gault (Fig. 5; Rod. 1-3) contain a number of dinoflagellate cyst species whose first appearances are thought (Clarke \& Verdier, 1967; Davey \& Verdier, 1973, 1976; Verdier, 1975; Fauconnier, 1975, 1979; Foucher, 1979, 1981; Costa \& Davey, 1992) to indicate strata of latest Albian, S. dispar Zone age. These include Cribroperidinium exilicristatum (Davey) Stover \& Evitt, Exochosphaeridium bifidum (Clarke \& Verdier) Clarke et al., Heterosphaeridium? heteracanthum (Deflandre \& Cookson) Eisenack \& Kjellstrom, Kleithriasphaeridium readei (Davey \& Williams) Davey \& Verdier, Leberidocysta defloccata (Davey \& Verdier) Stover \& Evitt,

\section{Explanation of Plate 2}

Representative Upper Albian-Lower Cenomanian dinoflagellate cysts from Cordebugle and Lewes. See Pl. 1 for conventions. Fig. 1. Disphaeria munda (Davey \& Verdier, 1973) Norvick in Norvick \& Burger, 1976. Rod. 1, MCP/1293. W22/2. Fig. 2. Stiphrosphaeridium anthophorum (Cookson \& Eisenack, 1958) Lentin \& Williams, 1985, Crd. 12, MCP/3165, Q53/1. Fig. 3. Ovoidinium scabrosum (Cookson \& Hughes, 1964) Davey, 1970, Crd. 1, MCP/3154, U27/1. Fig. 4. Ovoidinium verrucosum (Cookson \& Hughes, 1964) ostium (Davey, 1970) Lentin \& Williams, 1975, Rod. 4, MCP/1290, P47/4. Arrow indicates characteristic opening in the posterior pericoel. Fig. 5. Hystrichostrogylon membraniphorum Agelopoulos, 1964, Rod. 1, MCP/1293, G52/3. Fig. 6. Achomosphaera crassipellis (Deflandre \& Cookson, 1955) Stover \& Evitt, 1978, Rod. 3, MCP/1291, G37/1. Fig. 7. Ovoidinium verrucosum verrucosum (Cookson \& Hughes, 1964) Davey, 1970, Rod. 4, MCP/1290, L38/4. Fig. 8. Spiniferites twistringiensis (Maicr, 1959) Fensome et al., 1990, Rod. 1, MCP/1293, M46/1. Fig. 9. Pterodinium cingulatum cingulatum (O. Wetzcl, 1933) Below, 1981, Rod. 1, MCP/1293, M52/4. Fig. 10. Pterodinium cingulatum reticulatum (Davey \& Williams, 1966) Lentin \& Williams, 1981, Rod. 2, MCP/1292, W36/3. Fig. 11. Protoellipsodinium spinocristatum Davey \& Verdier, 1971, Crd. 1. MCP/3154, M29/4. Fig. 12. Ellipsodinium rugulosum Clarke \& Verdier, 1967, Rod. 1, MCP/1293, T32. Fig. 13. Dapsilidinium ambiguum (Deflandre, 1937b) Wheeler \& Sarjean1, 1990, Rod. 1, MCP/1293, G37/4. Fig. 14. Oligosphaeridium reticulatum Davey \& Williams, 1966, Rod. 4, MCP/1290, Q50/1. Fig. 15. Cleistosphaeridium clavulum (Davcy, 1969) Below, 1982, Crd. 2, MCP/3155, H18. 


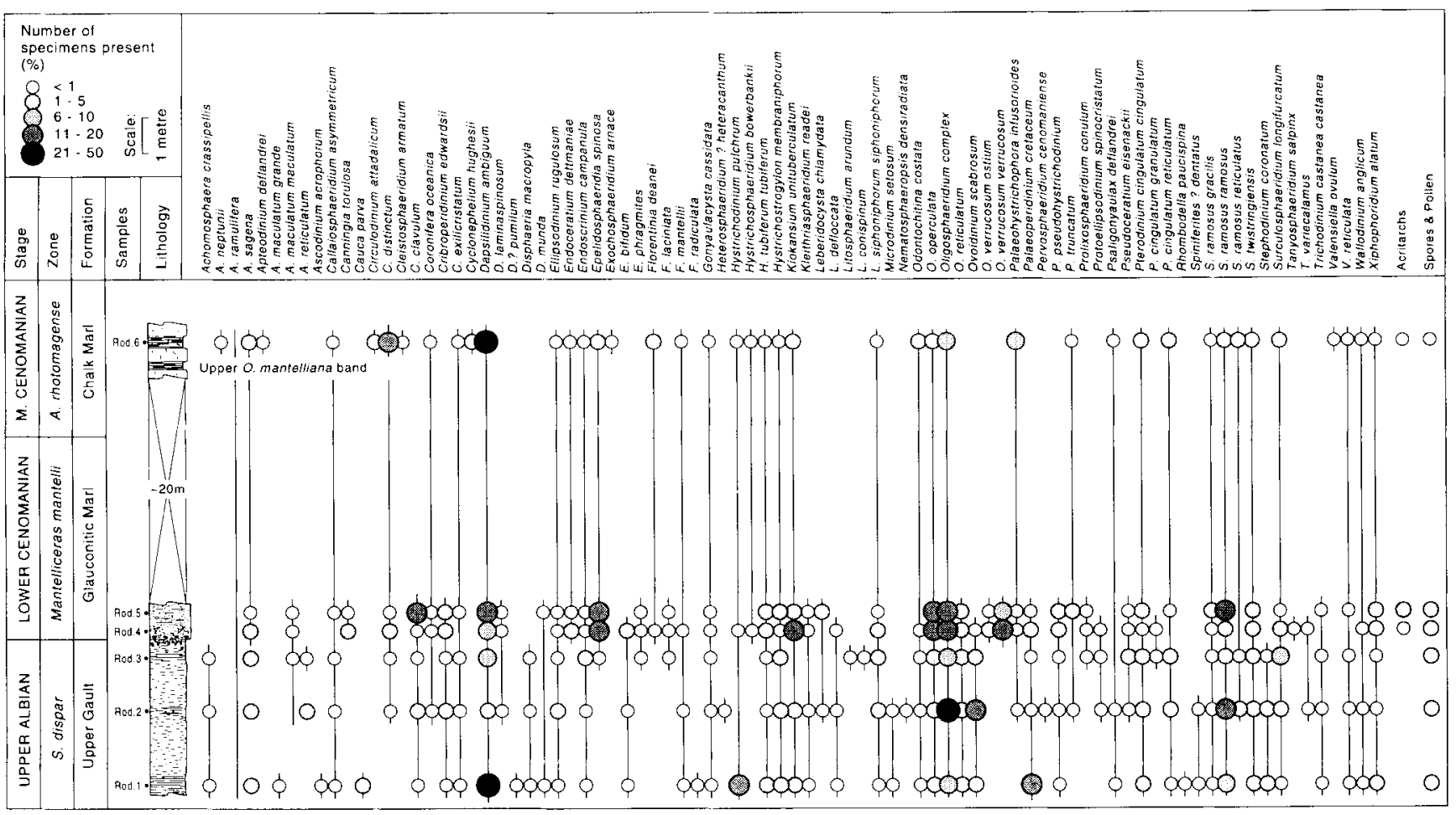

Fig. 5. Stratigraphy and palynomorph distribution across the Albian-Cenomanian boundary at Rodmell Cement Works, Lewes. Cyst abundances reported as percentages, based on counts of 200 specimens per slide. See Fig. 2 for lithological key.

Litosphaeridium siphoniphorum siphoniphorum (Cookson \& Eisenack) Davey \& Williams; emend. Lucas-Clark (Pl. 1, fig. 12), Odontochitina costata Alberti; emend. Clarke \& Verdier, Palaeohystrichophora infusorioides Deflandre and Pervosphaeridium pseudohystrichodinium (Deflandre) Yun. The last appearances of Rhombodella paucispina (Alberti) Duxbury and Apteodinium maculatum grande (Cookson \& Hughes) Below in our basal sample (Rod. 1), and those of Litosphaeridium arundum (Eisenack \& Cookson) Davey emend. Lucas-Clark and L. conispinum in sample Rod. 3, are also regarded as being indicative of the uppermost Albian (Foucher, 1981; Costa \& Davey, 1992).

Overall, the dinoflagellate cysts assemblages recovered from the Upper Gault at Rodmell are representative of the Upper Albian. However, Oligosphaeridium reticulatum Davey \& Williams (Pl. 2, fig. 14) must have a more extensive range than recorded previously from the Anglo-Paris Basin. This species has not been described before from pre-Cenomanian sediments (Davey \& Williams, 1966; Davey, 1969; Foucher, 1979), yet is common in all of our Upper Gault material (Fig. 4).

A number of taxa present as minor components of our assemblages (Fig. 5; Appendix 1), have not been recorded before from the Anglo-Paris Basin. Apteodinium reticulatum Singh (Rod. 3; Pl. 1, fig. 3) was first described (Singh, 1971) from the Upper Albian of Canada. Disphaeria macropyla Cookson \& Eisenack; emend. Norvick (Rod. 2, 3; Pl. 1, fig. 8) was originally described from the Turonian of Australia by Norvick (1976), although Morgan (1980) also reported this species as occurring in the uppermost Upper Albian $S$. dispar Zone of Australia. Nematosphaeropsis densiradiata Cookson \& Eisenack (Rod. 2) was previously known only from the low-Upper Albian, Mortoniceras (Mortoniceras) inflatum Zone of Australia (Morgan, 1980), while Pervosphaeridium cenomaniense (Norvick) Below (Rod. 2) has only been recorded previously from AlbianCenomanian sequences in Australia (e.g. Norvick, 1976).

Glauconitic Marl The upper beds of the Glauconitic Marl at Rodmell have yielded a sparse and unusual unphosphatized basal Lower Cenomanian $M$. mantelli Zone, $N$. carcitanense Subzone ammonite fauna, including numerous heteromorphs (Neostlingoceras, Idiohamites), Schloenbachia and, locally, Stoliczkaia (Lamnayella) (Kennedy, 1969; Wright \& Kennedy, 1984). The occurrence of Stoliczkaia is noteworthy given that Mantelliceras, the definitive Cenomanian genus (Birkelund et al., 1984), is known to be derived from a Stoliczkaia stock (Hancock, 1991), yet is itself unrecorded from the basal Glauconitic Marl at Rodmell. The ammonite assemblage recorded, therefore, appears to retain some Albian affinities.

The bottom of the Glauconitic Marl marks the appearance of keeled planktonic foraminifera, particularly Rotalipora appenninica (Renz), definitive of the Upper Albian-Lower Cenomanian $R$. appenninica Zone (UKP.1 of Hart et al., 1989). However, the basal Glauconitic Marl contains a benthonic foraminiferal assemblage which indicates the upper part of the Lower Cenomanian Flourensina intermedia/Arenobulimina anglica Concurrent Range Zone (Zone 8 of Carter \& Hart, 1977; UKB.2 of Hart et al., 1989), demonstrating that in addition to Zone 6a, 
Zone 7 (UKB.1) and the lower portion of Zone 8 (UKB.2) are also unrepresented. A comparable, and often greater, stratigraphic gap occurs throughout most of southern England (Carter \& Hart, 1977) and northern France (Robaszynski et al., 1980; Amédro, 1983, 1992; Robaszynski \& Amédro, 1986), and is equivalent to several metres of sediment in the more complete borehole sections described from Folkestone, East Kent, and offshore in the English Channel (La Manche).

Samples from the Glauconitic Marl (Rod. 4, 5) contain a number of species whose first appearances lie (Davey \& Verdier, 1973; Foucher, 1979, 1981; Fauconnier, 1979; Costa \& Davey, 1992) within the Upper Albian S. dispar Zone of the Anglo-Paris Basin. These are: Achomosphaera sagena Davey \& Williams; Canningia torulosa; Ovoidinium verrucosum verrucosum (Pl. 2, fig. 7); Endoceratium dettmanniae (Cookson \& Hughes) Stover \& Evitt; emend. Harding \& Hughes; Florentinia deanei; Hystrichosphaeridium bowerbankii. Most of these are minor elements of the flora, except $O$. verrucosum verrucosum which occurs commonly in, and is restricted to, the Glauconitic Marl.

Protocllipsodinium spinocristatum Davey \& Verdier, a species which is thought to last occur in the Upper Albian Mortoniceras (Mortoniceras) inflatum ammonite Zone, is recorded from the Upper Gault ( $S$. dispar Zone) and a single specimen also occurred in our basal Glauconitic Marl sample (Rod. 4). However, the observed angular discordance, the associated sudden facies change from silty clays to coarse glauconitic sands, and the proven hiatus at the contact, would suggest that this last specimen is most likely a remanié element in the assemblage. Similarly, the coincident first appearances of some rarer species might be a consequence of condensation at the contact.

Several species, whose last appearances are thought to occur within the lowest Cenomanian (Foucher, 1981), occur in the Glauconitic Marl at Rodmell. These include Ovoidinium scabrosum, $O$. verrucosum verrucosum, Palaeoperidinium cretaceum Pocock; emend. Davey; emend. Harding (Pl. 1, fig. 9), Pterodinium cingulatum (O. Wetzel) reticulatum (Davey \& Williams) Lentin \& Williams (PI. 2, fig. 10) and Canningia torulosa. In addition, the last appearance of Disphaeria munda (Davey \& Verdier) Norvick in sample Rod. 5, suggests a slightly younger age for this species than the previously published Late Albian top occurrence (e.g. Davey \& Verdier, 1973). With one exception ( $P$. cingulatum reticulatum), all of these taxa are absent in our sample from the upper part of the Chalk Marl (Fig. 5), which is consistent with them disappearing within the Lower Cenomanian. However, we have taken too few samples to place their last occurrences more precisely. Our records of $P$. cingulum reticulatum in the Middle Cenomanian indicates a more extensive range for this species.

Ovoidinium verrucosum ostium (Pl. 2, fig. 4) and Tanyosphaeridium salpinx, species which have not been recorded previously from the Anglo-Paris Basin, both occur in our basal Glauconitic Marl sample (Rod. 4). This confirms our records of these taxa from the basal Craie glauconieuse (Lower Cenomanian $M$. mantelli Zone) at
Cordebugle (see above) and suggests that they probably have a widespread occurrence within the Anglo-Paris Basin. Chalk Marl The upper $O$. mantelliana band constitutes the summit of the low Middle Cenomanian ammonite Acanthoceras rhotomagense Zone, Turrilites costatus Subzone (Kennedy, 1969; Wright \& Kennedy, 1984), and also coincides with the top of the planktonic foraminiferal Rotalipora reicheli Zone (UKP.2). This level lies within the benthonic foraminiferal $P$. cenomana Interval Zone (UKB.5 of Hart et al., 1989), at the summit of Zone 11(i) of Carter \& Hart (1977; Arenobulimina anglica/Plectina cenomana Concurrent Range Zone); its top marks the so-called mid-Cenomanian non-sequence, above which there is a sudden and marked increase in the planktonic/benthonic ratio of the foraminiferal assemblages. The base of the mid-Middle Cenomanian ammonite $T$. acutus Subzone is taken at the top of the brachiopod band.

Stratigraphically significant species are rare in our single Chalk Marl sample (Rod. 6). However, the continued presence of Cribroperidinium exilicristatum, Endoceratium dettmanniae and Epelidosphaeridia spinosa (Cookson \& Hughes) Davey, are consistent with this part of the sequence being no younger than Middle to early Late Cenomanian (Foucher, 1981; Jarvis et al., 1988; Costa \& Davey, 1992).

\section{DISCUSSION}

Palynomorph assemblages recovered from Cordebugle are of moderate abundance and diversity (Fig. 3). However, in the upper part of the Glauconie de base and lowest Craie glauconieuse de St Jouin, these assemblages are dominated to a large extent by specimens of Ovoidinium (particularly $O$. verrucosum verrucosum) and bisaccate pollen grains. This dominance continues up to sample Crd. 10 (a level yielding common Schloenbachia ammonites), above which Ovoidinium disappears and assemblages consist predominantly of Cleistosphaeridium clavulum (Davey) Below (Pl. 2, fig. 15), Circulodinium distinctum (Deflandre \& Cookson) Jansonius (PI. 1, fig. 13) and Epelidosphaeridia spinosa (Cookson \& Hughes) Davey. This change is associated with declining glauconite and the appearance of silicified nodules in the sediment, but takes place below the major facies change to flinty marls which occurs somewhat higher, above the Livet Omission Surface (Fig. 3).

Dinoflagellate cyst assemblages from Lewes are more abundant and diverse than those from Cordebugle, but are similar in a number of respects. The genus Ovoidinium is again a major component throughout the uppermost Upper Albian-basal Lower Cenomanian, but particularly in the lowest Lower Cenomanian Glauconitic Marl where $O$. verrucosum verrucosum appears in large numbers. At both localities Ovoidinium scabrosum is essentially replaced by $O$. verrucosum verrucosum close to, and most probably at, the Albian-Cenomanian boundary and Cleistosphaeridium clavulum is abundant in the uppermost beds yielding Ovoidinium. However, other elements of the flora, particularly Dapsilidinium ambiguum (Deflandre) Wheeler \& Sarjeant (Pl. 2, fig. 13), Epelidosphaeridia spinosa, Kiokansium unituberculatum (Tasch) Stover \& Evitt, 
Odontochitina operculata (O. Wetzel) Deflandre \& Cookson, Oligosphaeridium complex and Spiniferites ramosus ramosus (Ehrenberg) Mantell are also important components of assemblages recovered across the stage boundary at Lewes. These latter taxa occur, but do not represent major components of coeval assemblages at Cordebugle. Furthermore, terrestrially derived material represents a much greater proportion of the palynofacies at Cordebugle. These differences reflect the contrasting palaeogeographic settings of the two sites. Cordebugle was situated in a shallower-water sediment-starved marginal environment close to the western edge of the Anglo-Paris Basin. In contrast, Lewes was located in a deeper basinal setting far removed from continental influences, promoting increased phytoplankton productivity and diversity but reduced terrestrial input.

\section{CONCLUSIONS}

The last appearances of Litosphaeridium conispinum Davey \& Verdier; emend. Lucas-Clark and Protoellipsodinium spinocristatum Davey \& Verdier occur in the high Upper Albian $S$. dispar Zone (M. (M.) rostratum Subzone) and not in the low-mid-Upper Albian $M$. $(M$.) inflatum Zone as suggested by previous workers. The last occurrence of Rhombodella paucispina (Alberti) Duxbury is confirmed as being Upper Albian in this region. The range of Oligosphaeridium reticulatum Davey \& Williams is extended down into the Upper Albian $M$. (M.) rostratum Subzone.

The last appearances of Canningia torulosa Davey \& Verdier and Ovoidinium verrucosum verrucosum (Cookson \& Hughes) Davey lie within the lowest Lower Cenomanian Mantelliceras mantelli Zone (N. carcitanense Subzone). The latter taxa replaces $O$. scabrosum (Cookson \& Hughes) Davey, forming a major component of the cyst assemblage at the base of the Cenomanian at Rodmell and dominates the stage boundary transition at Cordebugle; the appearance of $O$. verrucosum verrucosum potentially represents a basal Cenomanian marker event. Ovoidinium verrucosum (Cookson \& Hughes) ostium (Davey) Lentin \& Williams, recorded for the first time in NW Europe, forms a minor element of our basal Cenomanian assemblages.

Apteodinium reticulatum Singh, Disphaeria macropyla Cookson \& Eisenack; emend. Norvick, Nematosphaeropsis densiradiata (Cookson \& Eisenack) Stover \& Evitt and Pervosphaeridium cenomaniense (Norvick) Below occur in the Upper Albian $S$. dispar Zone $(M$. (M.) rostratum Subzone); all four taxa are recorded for the first time from the Anglo-Paris Basin. Tanyosphaeridium salpinx Norvick, also previously unknown from NW Europe, is recorded from the basal Lower Cenomanian.

The range of Pterodinium cingulum (O. Wetzel) reticulatum (Davey \& Williams) Lentin \& Williams is extended up into the Middle Cenomanian A. rhotomagense Zone ( $T$. costatus Subzone).

\section{ACKNOWLEDGEMENTS}

Initial phases of this research were undertaken at the School of Earth Sciences, University of Greenwich (previously part of City of London Polytechnic). Subsequent support from the University of Wales, Aberystwyth and Kingston University is gratefully acknowledged.

\section{APPENDIX 1}

List of dinoflagellate cyst taxa recorded (for further taxonomic details and references see Lentin \& Williams, 1993). Locality records $(\mathrm{C}=$ Cordebugle; $\mathrm{R}=\mathrm{Rodmell})$ and figured taxa (details in parentheses) are indicated.

Achomosphaera crassipellis (Deflandre \& Cookson, 1955)

Stover \& Evitt, 1978; C, R (Pl. 2, fig. 6).

A. neptunii (Eisenack, 1958) Davey \& Williams, 1966; C, R

A. ramulifera (Deflandre, 1937) Evitt, 1963; C, R.

A. sagena Davey \& Williams, 1966; C, R.

Apteodinium deflandrei (Clarke \& Verdier, 1967) LucasClark, 1987; R.

A. maculatum (Eisenack \& Cookson, 1960) grande (Cookson \& Hughes, 1964) Below, 1981; R (Pl. 1, fig. 1).

A. maculatum maculatum Eisenack \& Cookson, 1960; C, R (Pl. 1, fig. 7).

A. reticulatum Singh, 1971; R (Pl. 1, fig. 3).

Ascodinium acrophorum Cookson \& Eisenack, 1960: R.

Callaiosphaeridium asymmetricum (Deflandre \& Courteville, 1939) Davey \& Williams, 1966; C, R.

Canningia torulosa Davey \& Verdier, 1973; C, R.

Canninginopsis colliveri (Cookson \& Eisenack, 1960) Backhouse, 1988; C.

Cauca parva (Alberti, 1961) Davey \& Verdier, 1971

Circulodinium attadalicum (Cookson \& Eisenack, 1962) Helby, 1987: R.

C. distinctum (Deflandre \& Cookson, 1955) Jansonius, 1986; C, R (Pl. 1, fig. 13).

Cleistosphaeridium armatum (Deflandre, 1937) Davey, 1969; $\mathrm{C}, \mathrm{R}$.

C. clavulum (Davey, 1969) Below, 1982; C, R (Pl. 2, fig. 15).

Coronifera oceanica Cookson \& Eisenack, 1958; emend. May, 1980: C, R (Pl. 1, fig. 6).

Cribroperidinium edwardsii (Cookson \& Eisenack, 1958) Davey, 1969; C, R.

C. exilicristatum (Davey, 1969) Stover \& Evitt, 1978; C, R. Cyclonephelium hughesii Clarke \& Verdier, 1967; C, R.

C. membraniphorum Cookson \& Eisenack, 1962; C.

Dapsilidinium ambiguum (Deflandre, 1937) Wheeler \& Sarjeant, 1990; C, R (Pl. 2, fig. 13).

D. Laminaspinosum (Davey \& Williams, 1966) Lentin \& Williams, 1981; C, R.

D.? pumilum (Davey \& Williams, 1966) Lentin \& Williams, 1981; C, R.

Disphaeria macropyla Cookson \& Eisenack 1960; emend.

Norvick in Norvick \& Burger, 1976; R (Pl. 1, fig. 8).

D. munda (Davey \& Verdier, 1973) Norvick in Norvick \& Burger, 1976; C, R (Pl. 2, fig. 1).

Ellipsodinium rugulosum Clarke \& Verdier, 1967; C, R (PI. 2, fig. 12).

Endoceratium dettmanniae (Cookson \& Hughes, 1964) Stover \& Evitt, 1978; emend. Harding \& Hughes, 1990; C, $\mathrm{R}$.

Endoscrinium campanula (Gocht, 1959) Vozzhennikova, 1967; C, R. 
Epelidosphaeridia spinosa (Cookson \& Hughes, 1964) Davey, 1969; C, R.

Exochosphaeridium arnace Davey \& Verdier, 1973; R.

E. bifidum (Clarke \& Verdier, 1967) Clarke et al., 1968; C, $\mathrm{R}$.

E. phragmites Davey et al., 1966; C, R.

Florentinia deanei (Davey \& Williams, 1966) Davey \& Verdier, 1973; C, R.

F. laciniata Davey \& Verdier, 1973; C, R (Pl. 1, fig. 2).

F. mantellii (Davey \& Williams, 1966) Davey \& Verdier, 1973; C, R.

F. radiculata (Davey \& Williams, 1966) Davey \& Verdier, 1973; emend. Davey \& Verdier, 1976; R.

Gonyaulacysta cassidata (Eisenack \& Cookson, 1960) Sarjeant, 1966; R.

Heterosphaeridium? heteracanthum (Deflandre \& Cookson, 1955) Eisenack \& Kjellstrom, 1971; R.

Hystrichodinium pulchrum Deflandre, 1935; C, R.

Hystrichosphaeridium bowerbankii Davey \& Williams, 1966; C. R.

H. tubiferum tubiferum (Ehrenberg, 1838) Deflandre, 1937; emend. Davey \& Williams, 1966; C, R.

Hystrichostrogylon membraniphorum Agelopoulos, 1964; C. $\mathrm{R}$ (Pl. 2, fig. 5).

Kiokansium unituberculatum (Tasch, 1964) Stover \& Evitt, 1978; C, R.

Kleithriasphaeridium readei (Davey \& Williams, 1966) Davey \& Verdier, 1976; C, R.

Leberidocysta chlamydata (Cookson \& Eisenack, 1962) Stover \& Evitt, 1978; emend. Fechner, 1985; emend. Marheinecke, 1992; C, R.

L. defloccata (Davey \& Verdier, 1973) Stover \& Evitt, 1978; $\mathrm{C}, \mathrm{R}$.

Litosphaeridium arundum (Eisenack \& Cookson, 1960) Davey, 1979; emend. Lucas-Clark, 1984; R (PI. 1, fig. 11).

L. conispinum Davey \& Verdier, 1973; emend. Lucas-Clark, 1984; C, R (Pl. 1, fig. 10).

L. siphoniphorum siphoniphorum (Cookson \& Eisenack, 1958) Davey \& Williams, 1966; emend. Lucas-Clark, 1984; C, R (Pl. 1, fig. 12).

Microdinium setosum Sarjeant, 1966; emend. Below, 1987; C, R.

Nematosphaeropsis densiradiata (Cookson \& Eisenack, 1962) Stover \& Evitt, 1978; R.

Odontochitina costata Alberti, 1961; emend. Clarke \& Verdier, 1967; C, R.

O. operculata (O. Wetzel, 1933) Deflandre \& Cookson, 1955; C, R.

Oligosphaeridium complex (White, 1842) Davey \& Williams, 1966; C, R (PI. 1, fig. 4).

O. reticulatum Davey \& Williams, 1966; C, R (Pl. 2, fig. 14).

Ovoidinium scabrosum (Cookson \& Hughes, 1964) Davey, 1970; C, R (Pl. 2, fig. 3).

O. verricosum (Cookson \& Hughes, 1964) ostium (Davey, 1970) Lentin \& Williams, 1975; C, R (Pl. 2, fig. 4).

$O$. verrucosum verrucosum (Cookson \& Hughes, 1964) Davey, 1970; C, R (Pl. 2, fig. 7).

Palaeohystrichophora infusorioides Deflandre, 1935; C, R.

Palaeoperidinium cretaceum Pocock, 1962; emend. Davey,
1970; emend. Harding, 1990; C, R (Pl. 1, fig. 9).

Pervosphaeridium cenomaniense (Norvick in Norvick \& Burger, 1976) Below, 1982; R.

P. pseudhystrichodinitum (Deflandre, 1937) Yun, 1981; C, $\mathrm{R}$.

P. truncatum (Davey, 1969) Below, 1982; emend. Masure 1988; emend. Harker in Harker et al., 1990; C, R.

Prolixosphaeridium conulum Davey, 1969; C, R.

Protoellipsodinium spinocristatum Davey \& Verdier, 1971; C, R (Pl. 2, fig. 11).

Psaligonyaulax deflandrei Sarjeant, 1966; emend. Sarjeant, 1982; R.

Pseudoceratium eisenackii (Davey, 1969) Bint, 1986; C, R.

Pterodinium cingulatum cingulatum (O. Wetzel, 1933) Below, 1981; C, R (Pl. 2, fig. 9).

$P$. cingulatum (O. Wetzel, 1933) granulatum (Clarke \& Verdier, 1967) Lentin \& Williams, 1981; C, R.

$P$. cingulatum (O. Wetzel, 1933) reticulatum (Davey \& Williams, 1966) Lentin \& Williams, 1981; C, R (Pl. 2, fig. 10).

Rhombodella paucispina (Alberti, 1961) Duxbury, 1980; R.

Spiniferites? dentatus (Gocht, 1959) Lentin \& Williams, 1973; emend. Duxbury, 1977; R.

S. ramosus gracilis (Davey \& Williams, 1966) Lentin \& Williams, 1973; C, R.

$S$. ramosus ramosus (Ehrenberg, 1838) Mantell, 1854; C, R.

S. ramosus reticulatus (Davey \& Williams, 1966) Lentin \& Williams, 1973; R.

S. twistringiensis (Maier, 1959) Fensome et al., 1990; C, R (Pl. 2, fig. 8).

Stephodinium coronatum Deflandre, 1936; R (Pl. 1, fig. 5).

Stiphrosphaeridium anthophorum (Cookson \& Eisenack, 1958) Lentin \& Williams, 1985; C (Pl. 2, fig. 2).

Surculosphaeridium? longifurcatum (Firtion, 1952) Davey et al., 1966; C, R.

Tanyosphaeridium salpinx Norvick in Norvick \& Burger, 1976; C, R.

T. variecalamus Davey \& Williams, 1966; C, R.

Trichodinium castanea castanea (Deflandre, 1935) Clarke \& Verdier, 1967; R.

Valensiella ovulum (Deflandre, 1947) Eisenack, 1963; emend. Courtinat, 1989; R.

$V$. reticulata (Davey, 1969) Courtinat, 1989; $\mathrm{R}$.

Wallodinium anglicum (Cookson \& Hughes, 1964) Lentin \& Williams, 1973; R.

Xenascus ceratioides (Deflandre, 1937) Lentin \& Williams, 1973; C.

Xiphophoridium alatum (Cookson \& Eisenack, 1962) Sarjeant, 1966; C, R.

\section{Manuscript received November 1993 Manuscript accepted June 1994}

\section{REFERENCES}

Amédro, F. 1983. L'Albien de la bordure septentrionale du bassin de Paris. Mise en évidence d'un contrôle tectonique de la sédimentation. Géologie de la France, 3: 179-192.

Amédro, F. 1992. L'Albien du bassin anglo-parisien : Ammonites, zonation phylétique, séquences. Bulletin Centres de Recherches Exploration-Production Elf-Aquitaine, 16: 187-233. 
Birkelund, T., Hancock, J. M., Hart, M. B., Rawson, P. F. Remane, J., Robaszynski, F., Schmid, F. \& Surlyk, F. 1984. Cretaceous stage boundaries-proposals. Bulletin of the Geological Society of Denmark, 33: 3-20.

Carter, D. J. \& Hart, M. B. 1977. Aspects of mid-Cretaceous stratigraphical micropalaeontology. Bulletin of the British Museum (Natural History) Geology, 29: 1-135.

Clarke, R. F. A. \& Verdier, J. P. 1967. An investigation of microplankton assemblages from the Chalk of the Isle of Wight, England. Verhandelingen Koninklijke Nederlandse Akadamie van Wetenschappen Afdeling Natuurkunde, Eerste Reeks, 24: 1-96.

Cooper, M. R., 1977. Eustacy during the Cretaceous: its implications and importance. Palaeogeography Palaeoclimatology Palaeocology, 22: 1-60.

Costa, L. I. \& Davey, R. J. 1992. 3. Dinoflagellate cysts of the Cretaceous System. In Powell, A. J. (Ed.), A Stratigraphic Index of Dinoflagellate Cysts, 99-154. British Micropalaeontological Society Series, Chapman \& Hall, London.

Davey, R. J. 1969. Non-calcareous microplankton from the Cenomanian of England, northern France and North America, Part I. Bulletin of the British Museum (Natural History) Geology, 17: $103-180$

Davcy, R. J. 1970. Non-calcarcous microplankton from the Cenomanian of England, northern France and North Amcrica, Part Il. Bulletin of the British Museum (Natural History) Geology, 18: $333-397$

Davey, R. J. \& Verdier, J. P. 1973. An investigation of microplankton assemblages from latest Albian (Vraconian) sediments. Revista Espanola de Micropaleontologia, 5, 173-212.

Davey, R. J. \& Verdier, J. P. 1976. A review of certain non-tabulate Cretaceous hystrichospherid dinocysts. Review of Palaeobotany and Palynology, 22: 307-335.

Davey, R. J. \& Williams, G. L. 1966. The genus Hystrichosphaeridium and its allies. In: Davey, R. J. et al. (Eds), Studies in Mesozoic and Cainozoic dinoflagellate cysts. Bulletin of the British Museum (Natural History) Geology Supplement, 3: $157-175$.

Fauconnier. D. 1975. Répartition des Peridiniens de l'Albien du Bassin de Paris. Rôle stratigraphique et liason avec le cadre sédimentologique. Bulletin Bureat de Recherches géologiques et minières (deuxième série), 1: 235-273.

Fauconnier, D. 1979. Les dinoflagellés de l'Albien et du Cénomanien inférieur du Bassin de Paris. Document Bureau de Recherches géologiques et minières, 5: 151 p.

Foucher, J. -C. 1979. Distribution stratigraphique des kystes de dinoflagellés et des acritarches dans le Crétacé supérieur du Bassin de Paris et de l'Europe septentrionale. Palaeontographica Abteilung B. 169: 78-105.

Foucher. J.-C. 1981. Kystes de dinoflagellés du Crétacé moyen européen: proposition d'une echelle biostratigraphique pour le domain nord-occidental. Cretaceous Research, 2: 331-338.

Gaster, C. T. A. 1929. Chalk zones in the neighbourhood of Shoreham, Brighton and Newhaven, Susscx. Proceedings of the Geologists" Association, 39: 328-340.

Hancock. J. M. 1989. Sea-level changes in the British region during the Late Cretaccous. Proceedings of the Geologists' Association, 100: $565-594$.

Hancock, J. M. 1990). Cretaccous. In Glennie, K. W. (Ed.), Introduction to the Petroleum Geology of the North Sea (3rd ed.), 255-272, Blackwell, Oxford

Hancock, J. M. 1991. Ammonite scales for the Cretaccous system. Cretaceous Research, 12: 159-291.

Hancock, J, M. 1992. Late Cretaceous. In Cope, J. C. W., Ingham J. K. \& Rawson, P. F. (Eds). Atlas of Palaeogeography and Lithofacies. Geological Society, London, Memoir, 13: 134- 139.

Hancock, J. M. \& Kauffmann, E. G. 1979. The great transgressions of the Late Cretaceous. Journal of the Geological Society, London, 136: 175-186.

Hay, B. U., Hardenbol, J. \& Vail, P. 1987. Chronology of fluctuating sea levels since the Triassic. Science, 235: 1156-1167.

Hart, M. B., Bailey, H. W., Crittenden. S., Fletcher, B. N., Price, R. J. \& Swiecicki, A. 1989. Cretaceous. In Jenkins, D. G. \& Murray,
J. W. (Eds), Stratigraphical Atlas of Fossil Foraminifera, British Micropalaeontological Society Series, 273-371, Ellis Horwood, Chichester.

Hart, M. B., Simmons, M. D. \& Williams, C. L. 1992. Sequence stratigraphy and sea-level changes in the mid-Cretaceous (Albian-Turonian) of southern England; a preliminary investigation. Proceedings of the Ussher Society, 8: 7-10.

Jarvis, I., Carson, G. A.. Cooper, M. K. E., Hart, M. B., Horne, D., Leary, P. N., Rosenfeld, A. \& Tocher, B. A. 1988. Microfossil assemblages and the Cenomanian-Turonian (late Cretaceous) Occanic Anoxic Event. Cretaceous Research, 9: 3-103.

Juignet, P. 1974. La transgression crétacée sur la bordure orientale du Massif armoricain. Thèse de Doctoral d'ćtat, l'Université do Caen.

Juignet, P. 1980. Transgressions-régressions, variations eustatiques et influences tectoniques de l'Aptien au Maastrichtian dans le Bassin de Paris occidental et sur la bordure de Massif Armoricain. Cretaceous Research, 1: 341--357.

Juignet, P. \& Breton, G. 1992. Mid-Cretaceous sequence stratigraphy and sedimentary cyclicity in the western Paris Basin. Palaeogeography Palaeoclimatology Palaeoecology, 91, 197-218.

Kennedy, W. J. 1969. The correlation of the Lower Chalk of south-east England. Proceedings of the Geologists' Association, 80: $459-560$

Lake, R. D., Young, B., Wood, C. J. \& Mortimore, R. N. 1987. Geology of the country around Lewes. Memoir British Geological Survey, Sheet 319 (England and Wales)

Lentin, J. K. \& Williams, G. L. 1993. Fossil dinoflagellates: index to genera and species. American Association of Stratigraphic Palvnologists, Contributions Series, 28.

Morgan, R. 1980. Palynostratigraphy of the Australian Early and Middle Cretaccous. Geological Survey of New South Wales Palaeontology Memoir, 18: 1-38.

Mortimore, R. N. \& Pomerol, B. 1987. Correlation of the Upper Cretaceous White Chalk (Turonian to Campanian) in the Anglo-Paris Basin. Proceedings of the Geologists' Association, 98: $97-143$.

Norvick, M. S. 1976. Mid-Cretaceous microplankton from Bathurst. In: Norvick, M. S. \& Burger, D. (Eds), Palynology of the Cenomanian of Bathurst Island, Northern Territory, Australia. Australia Bureau of Mineral Resources, Geologv and Geophysics Bulletin, 151: 21-113.

Price, R. J. 1977. The stratigraphical zonation of the Albian sediments of north-west Europe, as based on foraminifera. Proceedings of the Geologists' Association, 88: 65-91.

Rawson, P. F., Curry, D.. Dilley, F. C.. Hancock, J. M., Kennedy, W. J. Nealc, J. W., Wood, C. J. \& Worssam, B. C. 1978. A correlation of Cretaceous rocks in the British Isles. Gcological Society, London, Special Report, 9.

Robaszynski, F. \& Amédro, F. 1986. The Cretaceous of the Boulonnais (France) and a comparison with the Cretaceous of Kent (United Kingdom). Proceedings of the Geologists Association, 97: 171-208.

Robaszynski, F., Amédro, F., Foucher, J. -C., Gaspard, D. Magniez-Jannin, F., Manivit, H. \& Sornay, J. 1980. Synthèse biostratigraphique de l'Aptien au Santonien du Boulonnais á partir de sept groupes paléontologiques: foraminifères, nannoplancton, dinoflagellés et macrofaunes. Zonations micropaléontologiques integrées dans le cadre du Crétacés borćal nord-curopéen. Revue de Micropaléontologie, 22 195-321.

Robaszynski, F., Juignet, P., Gale, A. S., Amédro, F. \& Hardenbol, J. 1992. Sequence stratigraphy in the Upper Cretaceous of the Anglo-Paris Basin, exemplified by the Cenomanian stage. In Mesozoic and Cenozoic Sequence Stratigraphy of European Basins, Dijon, May 1992, Abstracts, p. 80

Simmons. M. D., Williams, C. L. \& Hart, M. B. 1991. Sea-level changes across the Albian-Cenomanian boundary in south-west England. Proceedings of the Ussher Society, 7: 408-412.

Singh, C. 1971. Lower Cretaceous microfloras of the Peace River area, northwestern Alberta. Research Council of Alberta Bulletin, 28: $301-542$ 
Dinoflagellate cysts of the Albian-Cenomanian boundary

Verdier, J-P. 1975. Les Kystes de dinoflagellés de la section de Wissant et leur distribution stratigraphique au Crétacé moyen. Revue de Micropaléontologie, 17: 191-197.

Wright, C. W. \& Kennedy, W. J. 1984. The Ammonoidea of the Lower Chalk. Part 1. Monograph of the Palaeontographical Society, London, 137: 1-126.
Wright, C. W. \& Kennedy, W. J. 1987a. The Ammonoidea of the Lower Chalk. Part 2. Monograph of the Palaeontographical Society, London, 139: 127-218.

Wright, C. W. \& Kennedy, W. J. 1987b. 7. Ammonites. In Owen, E. \& Smith, A. B. (Eds), Fossils of the Chalk. Palaeontological Association Field Guides to Fossils, 2: 141-182. 